\title{
JUVENILE DEVELOPMENT OF UCA (MINUCA) BURGERSI HOLTHUIS, 1967 (CRUSTACEA, BRACHYURA, OCYPODIDAE) IN THE LABORATORY
}

\author{
RONY R. R. VIEIRA ${ }^{1,3}$; GRASIELA L. L. PINHO ${ }^{1,4}$ \& PAULO J. RIEGER ${ }^{2,5}$ \\ ${ }^{1}$ Universidade Federal do Rio Grande, Instituto de Oceanografia- FURG - C. Postal 474, 96201-900, Rio Grande, RS, Brazil. ${ }^{2}$ Instituto Ciências \\ Biológicas, -FURG. ${ }^{3}$ ronycrab@yahoo.com; ${ }^{4}$ grasielapinho@hotmail.com; ${ }^{5} \mathrm{dmbpjr@furg.br}$
}

\begin{abstract}
RESUMO
Desenvolvimento juvenil de Uca (minuca) burgersi Holthuis, 1967 (Crustacea, Brachyura, Ocypodidae) em laboratório O caranguejo chama-maré Uca burgersi ocorre na costa leste Americana desde a Flórida até o Brasil (do Maranhão até São Paulo). Este artigo descreve o desenvolvimento juvenil de $U$. burgersi realizado em laboratório. Além disso, apresenta-se uma comparação da morfologia juvenil com outras espécies estudadas anteriormente e que possuem ocorrência no litoral brasileiro. Larvas de uma fêmea ovígera de $U$. burgersi eclodiram no laboratório e foram mantidas até o décimo estágio juvenil. O experimento foi realizado em câmara climática com temperatura de $25 \pm 1^{\circ} \mathrm{C}$, salinidade $34 \%$ o e fotoperíodo de $12 / 12$ horas. $\mathrm{O}$ primeiro caranguejo juvenil foi obtido 43 dias após a eclosão. Somente um espécimen alcançou o décimo estágio juvenil 174 dias após a eclosão. A morfologia do primeiro estágio juvenil foi descrita detalhadamente, bem como as mudanças morfológicas nos estágios subsequentes. A definição sexual ocorre no quarto estágio juvenil, o dimorfismo sexual ocorre no sexto estágio e o dimorfismo do quelípodo ocorre no sétimo estágio juvenil.
\end{abstract}

PALAVRAS CHAVE: Crustacea, Brachyura, Ocypodidae, Uca burgersi, Desenvolvimento Juvenil.

\section{ABSTRACT}

The fiddler crab Uca (Minuca) burgersi has been recorded in eastern American coast, from Florida to Brazil (from Maranhão to São Paulo). The juvenile stages of $U$. burgersi are described here based on material reared under laboratory conditions. Additionally a comparison of juvenile morphology is given for the juvenile of other species already studied with occurrence in the Brazilian coast. Larvae of $U$. burgersi were obtained from one ovigerous female hatched in the laboratory, which reached until the tenth juvenile stage. Rearing was conducted in a temperature-controlled climatic chamber at $25 \pm 1^{\circ} \mathrm{C}, 34 \%$ o salinity and $12 / 12$ (L/D) photoperiod. The first juvenile crab appeared at 43 days after hatching. Only one individual reached the tenth stage 174 days after hatching. The morphology of first juvenile crab was described as well as morphological changes throughout juvenile development. The sexual definition occurs in the fourth juvenile stage, abdominal dimorphism occurs in the sixth juvenile stage and chelipeds dimorphism occurs in the seventh juvenile stage.

KEY WORDS: Crustacea, Brachyura, Ocypodidae, Uca burgersi, Juvenile development.

\section{INTRODUCTION}

Of the 97 recognized Uca Leach, 1814 species (Rosenberg 2001), 10 occur along the Brazilian coast, distributed among the subgenera Minuca Bott, 1954, Leptuca Bott, 1973 and Uca Leach, 1814 (Melo 1996). The genus Uca is easily distinguished from other Brachyura genera by the occurrence of heterochely. Studies have already been conducted on species of Uca occurring on the Brazilian Coast, such as ecological investigations (Oliveira 1939, Coelho 1965/6, Coelho \& Ramos-Porto 1980, Lopez 1980, Genoni 1985, 1991, Santos et al. 1994, Botto \& Iribarne 2000, Kellmeyer \& Salmon 2001), larval development descriptions (Anger et al. 1990, Rieger 199619971998 \& 1999), population biology studies (Conde \& Diaz 1985, Spivak et al. 1991, Costa \& Negreiros-Fransozo 2002), reproduction (Salmon 1987, Colpo \& Negreiros-Fransozo 2003), evolution (Diniz-Filho 1990), phylogeny (Rosenberg 2001), and relative growth (Negreiros-Fransozo et al. 2003, Benetti \& Negreiros-Fransozo 2004).

The study of juvenile phase of Brachyura are very important for identification purposes, as most of the characters used in the identification of brachyurans are based upon descriptions of mature adults, whether either a juvenile or immature is caught, identification might be somewhat difficult, or even impossible, in the absence of appropriate morphological descriptions of these stages. The study of early crab stages also may help to establish phylogenies within Brachyura (Martin et al. 1984).

However, the descriptions of juvenile stages are only available for few crabs species, less than $10 \%$ in the case of ocypodids. Regarding to the genus Uca, Hyman (1920) described the juvenile stages of Uca pugilator (Bosc, 1802) (as Gelasimus pugilator Bosc, 1802) until $4 \mathrm{~mm}$ of carapace width; gross morphology of first and second stages of Uca panacea Novak \& Salmon (1974) was described by Novak \& Salmon (1974); Muraoka (1976) described the first juvenile stage of Uca lactea (de Haan, 1835) and O'Connor (1990) described the morphological differentiation of juveniles stages based on number of spoon-tipped setae on the meropodite of the second maxilliped of Uca pugilator and Uca pugnax (Smith, 1870). 
Uca (Minuca) burgersi Holthuis, 1967 is widely distributed over the eastern American Coast, as it is found in Florida, Gulf of Mexico, Antillas, Venezuela and Brazil (from Maranhão to São Paulo). It inhabits estuarine beaches, usually near to mangrove trees, living in burrows constructed in the intertidal zone (Melo 1996).

This paper describes the first crab juvenile stages of Uca burgersi reared under laboratory conditions and some alterations on the morphology of the nine subsequent juvenile stages. A comparison of juvenile morphology is given for the juvenile of other species already studied and than occur in the Brazilian coast.

\section{MATERIAL AND METHODS}

Uca burgersi ovigerous females were collected handly at Praia Dura (Ubatuba, São Paulo - Brazil). In the laboratory, the females were isolated in tanks with $10 \mathrm{~L}$ of filtered seawater, with salinity at $34 \%$ and continuous aeration until larval hatching. Tanks were kept in a BOD-eletrolab climatic chamber with controlled temperature $\left(25 \pm 1^{\circ} \mathrm{C}\right)$ and a photoperiod of $12 \mathrm{~h}$ of light and $12 \mathrm{~h}$ of dark. Females were not fed during this period.

Rearing method of larvae and description of larval development has been described by Rieger (1998). Each juvenile, 10 in total, was placed in an individual $50 \mathrm{~mL}$ acrylic jar with $20 \mathrm{~mL}$ of seawater at salinity $34 \%$. Afterwards, jars were transferred to the climatic chamber with the same temperature and photoperiod settings stated earlier. Juveniles were monitored daily to register mortality and verify the occurrence of ecdysis. Dead juveniles and exuviae were fixed in $96 \%$ alcohol and glycerin mixture at ratio of $1: 1$ (vol:vol). Jars were washed daily with freshwater. Juveniles were fed ad libitum with Artemia sp.

Carapace maximum length and width were recorded at each juvenile stage. Drawings and measurements were done in juveniles and exuviae using an Olympus BX-40 microscope equipped with camera lucida. The descriptions of appendages were based on Clark et al. (1998). Throughout the text, the following nomenclature was adopted: J-I, first stage juvenile; J-II, second stage juvenile; J-III, third juvenile stage, successively. Numbers presented in brackets means variation in the number of setae.

\section{RESULTS}

The first juvenile crab appeared 43 days after hatching. Only one individual reached the $10^{\text {th }}$ juvenile stage (174 days after hatching). The maximum, minimum and average duration of each stage of the juvenile phase is presented in Table I.

Table I - Uca burgersi Holthuis, 1967. Duration and survival of the juvenile stages starting from the hatching. $\bar{x}$, accumulated average (in days); D, minimum duration; D', maximum duration; $n$, number of alive individuals; $\dagger$, number of dead individuals and S\%, survival percentage.

\begin{tabular}{c|cccccccccc}
\hline & J-I & J-II & J-III & J-IV & J-V & J-VI & J-VII & J-VIII & J-IX & J-X \\
\hline $\bar{x}$ & 56.77 & 66.87 & 81.87 & 86 & 117.42 & 138.85 & 159 & 152.5 & 174 & \\
$\mathbf{D}$ & 43 & 49 & 57 & 74 & 94 & 123 & 136 & 148 & 174 \\
$\mathbf{D}$ & 66 & 82 & 108 & 124 & 144 & 172 & 185 & 157 & 174 \\
$\mathbf{n}$ & 10 & 9 & 8 & 8 & 7 & 7 & 7 & 6 & 2 & 1 \\
$\mathbf{T}$ & 1 & 1 & - & 1 & - & - & 1 & 4 & 1 \\
$\mathbf{S} \%$ & 90 & 80 & 80 & 70 & 70 & 70 & 60 & 20 & 10 & \\
\hline
\end{tabular}

Description of the first juvenile stage

Carapace (Figure 1a) dorsally convex, with sparsely distributed simple, small, and plumose setae.
Gastric, cardiac, intestinal and branchial regions not evident. Antero-lateral edges with minute teeth. 

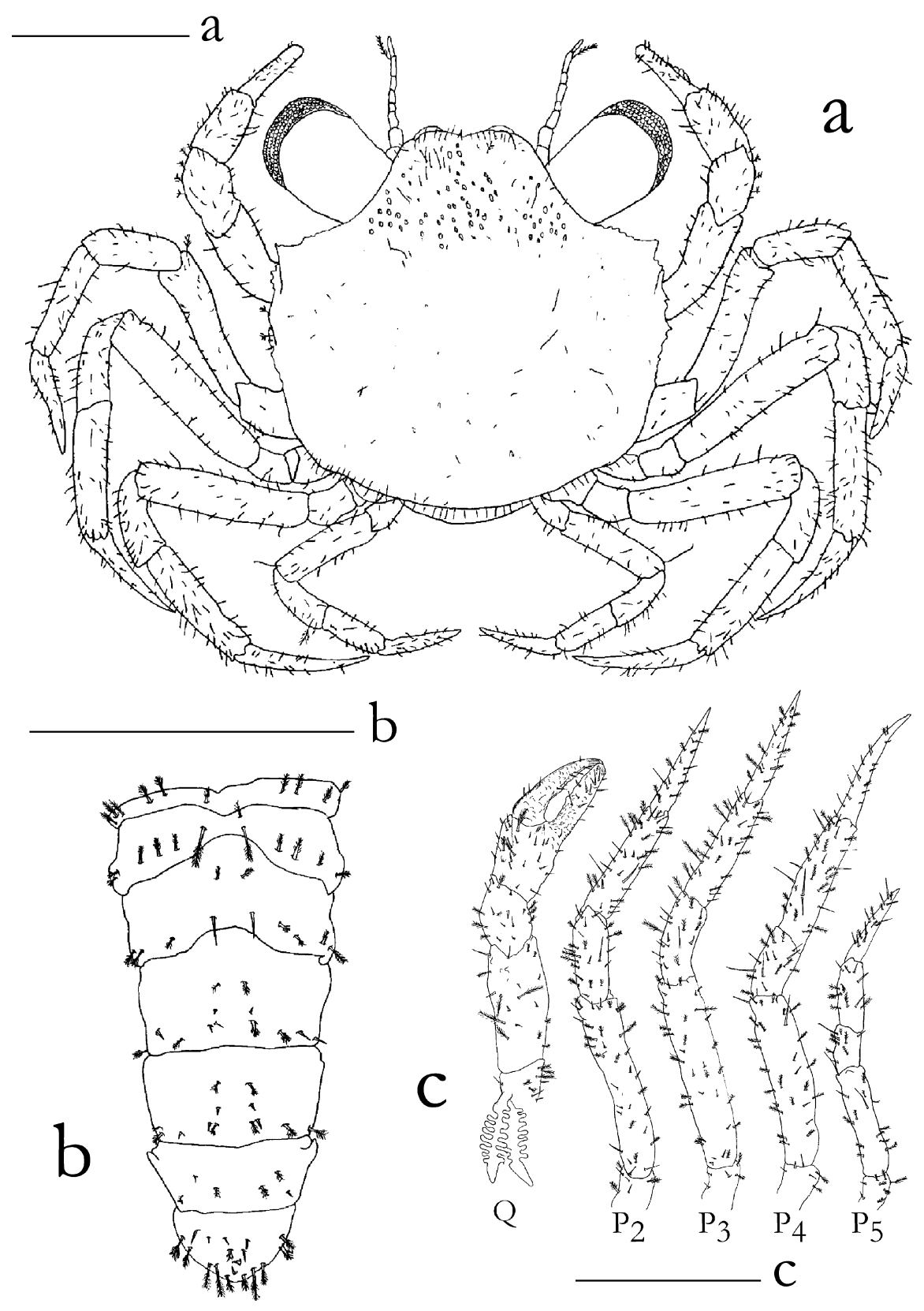

Figure 1 - Uca burgersi Holthuis, 1967. First juvenile stage, (a) dorsal view; (b) abdomen, dorsal view; (c) cheliped $(\mathrm{Q})$ and pereopods $\left(\mathrm{P}_{2}-\mathrm{P}_{5}\right)$. Scale bars $=0.5 \mathrm{~mm}$.

Antennule (Figure 2a) basal segment well developed with $17(13,15)$ plumose setae. Peduncle 2-segmented with 2(3) plumose setae on proximal segment; distal segment without setae. Endopod (ventral flagellum) unsegmented with 2 terminal simple setae. Exopod (dorsal flagellum) 3-segmented: proximal segment without setae; median segment with 1(2-3) simple setae, 5(6) aesthetascs; distal segment with 4(5) aesthetascs and without setae. 


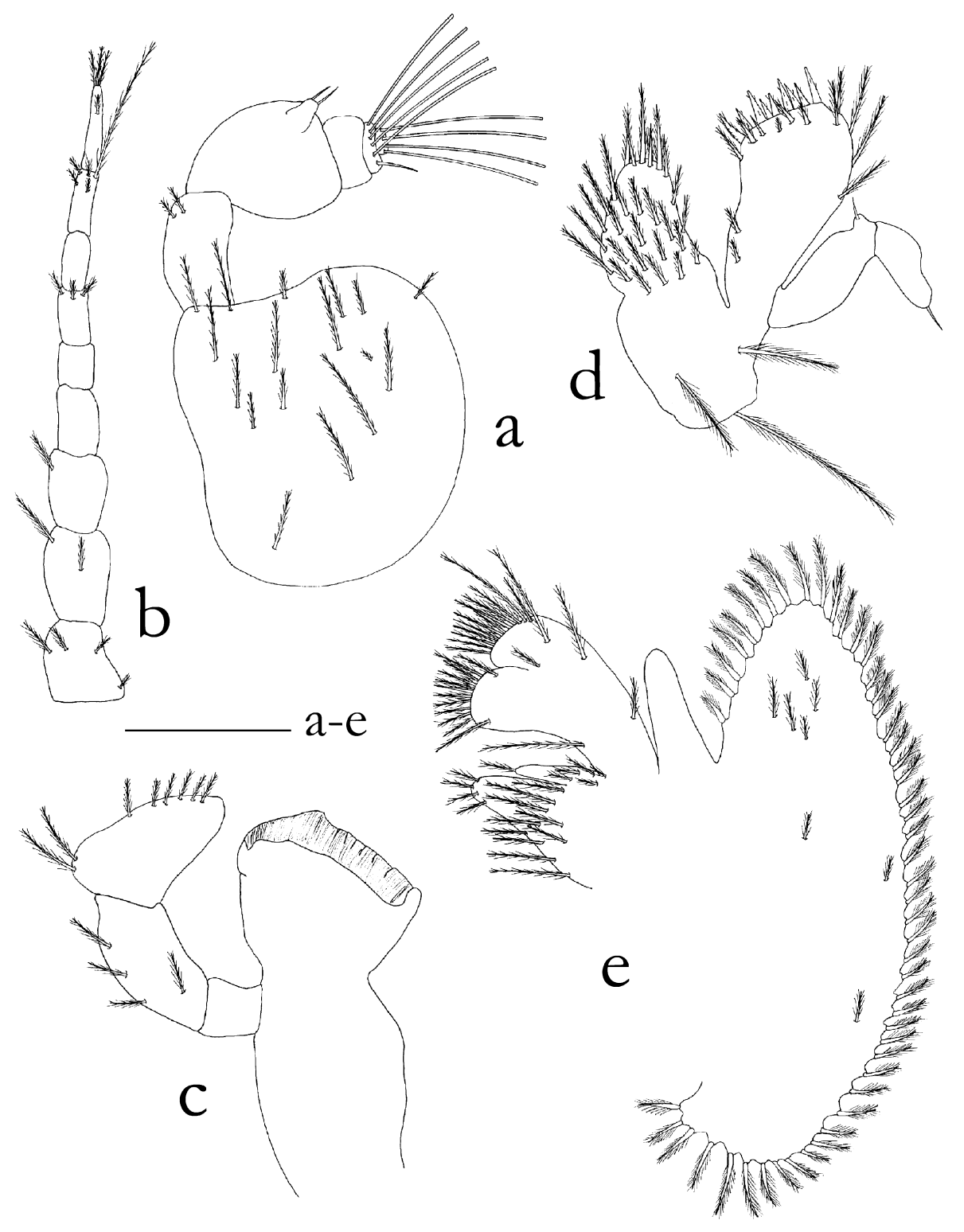

Figure 2 - Uca burgersi Holthuis, 1967. First juvenile stage, (a) antennule; (b) antenna; (c) mandible; (d) maxillule; (e) maxilla. Scale bar $=0.1 \mathrm{~mm}$.

Antenna (Figure 2b) peduncle 3-segmented with 4, 2(1), 1(2) plumose setae. Flagellum 6segmented with $0,0,3,0,5,1$ subterminal and (3)3 terminal plumose setae.

Mandible (Figure 2c) palp 3-segmented with 0, 4, 8 plumose setae.

Maxillule (Figure 2d) coxal endite with 28(2330) plumose setae. Basal endite with 22(20-23) plumose setae. Endopod 2-segmented with 1 simple seta in each segment. Protopod with 3(2) plumose setae.

Maxilla (Figure 2e) coxal endite bilobed with 14(15-17) plumose setae on proximal lobe; 6(7-8) plumose setae on distal lobe. Basal endite bilobed with 13(11-14) plumose setae on proximal lobe, and 16(14-15) plumose setae on distal lobe. Endopod unsegmented and without setae. Exopod (scaphognathite) with 51(46-50) marginal plumose setae and $8(9,10)$ simple setae on median surface.

First Maxilliped (Figure 3a) coxal endite with 21(20, 22-25) plumose setae. Basal endite with 34(3542) plumose setae. Endopod unsegmented with 24(20-23) plumose setae. Exopod 2-segmented with 5(6-7) plumose setae on proximal segment and 4 plumose setae on distal segment. Epipod triangular shaped, is well-developed, with 2 basal simple setae and 5(4) terminal simple setae. 


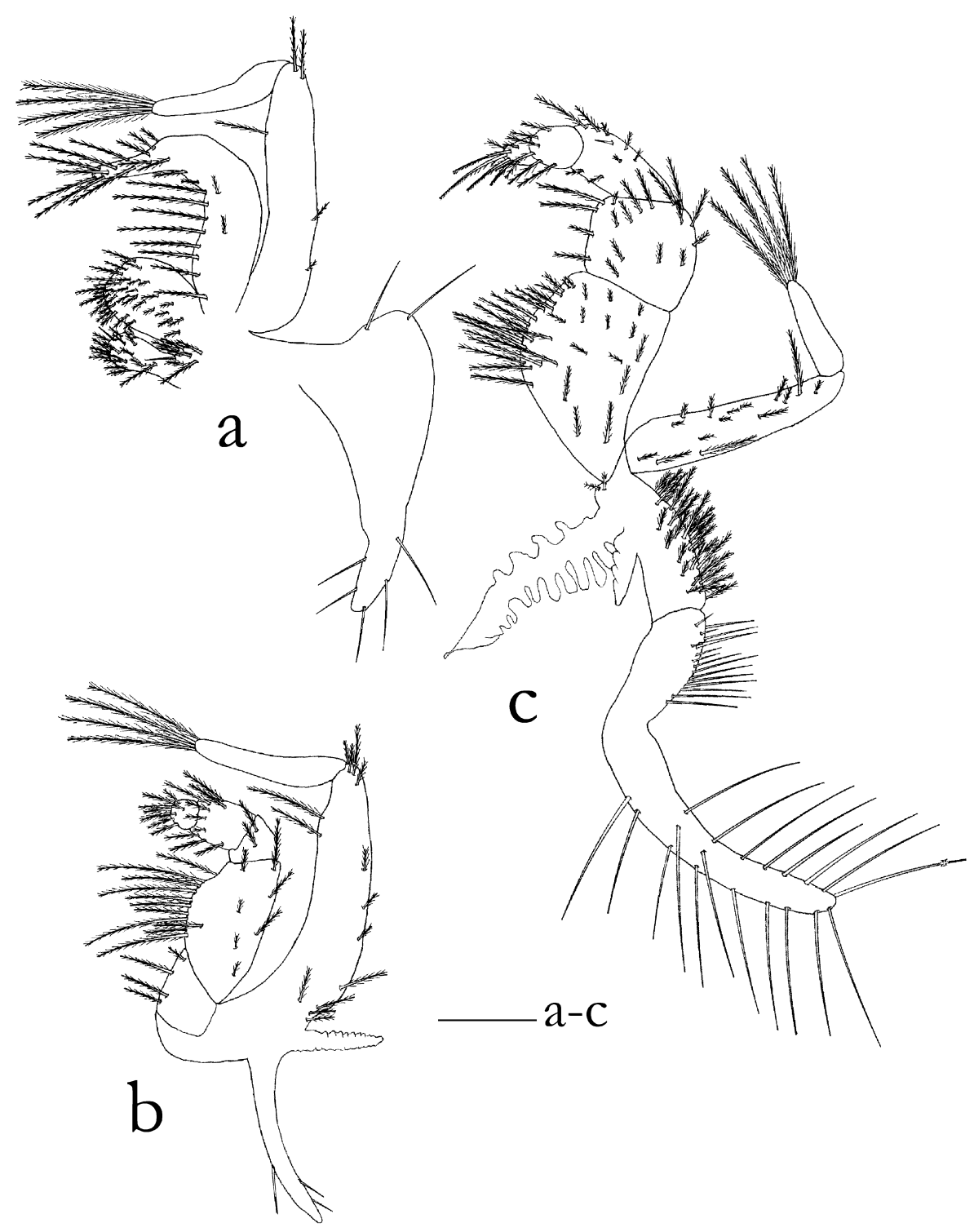

Figure 3 - Uca burgersi Holthuis, 1967. First juvenile stage, (a) first maxilliped; (b) second maxilliped; (c) third maxilliped. Scale bar $=0.1 \mathrm{~mm}$.

Second Maxilliped (Figure 3b) endopod 5segmented with 4, 18(16-19), 2, 9(10-11), 9(7-10) plumose setae. Exopod 2-segmented with 14(13) plumose setae on proximal segment; 4(3) plumose setae on distal segment. Epipod with 3 simple setae. Basis of epipod with a podobranchial bud.

Third Maxilliped (Figure 3c) endopod 5segmented with 33(34-40), 18(14-20), 9(10), 6(58),6(7) plumose setae. Exopod 2-segmented with 14(13-19) plumose setae on proximal segment; 4 plumose setae on distal segment. Protopod with 27(22-29) simple setae. Protopod with one posterior arthrobranchial and a podobranchial buds. Epipod with 16(17) basal simple setae, 19(15-18) terminal simple setae, one of them having anchors.

Abdomen (Figure 1b) with six somites and telson folded under carapace; somites wider than longer, with small, simple and plumose setae dorsally. Abdominal somites, from second to fifth, with four pairs of pleopods (Figure $6 \mathrm{~J}-\mathrm{I}$ ) without setae; uropods absent.

Chelipeds (Figure 1c-Q) symmetrical with sparse and plumose setae; two arthrobranchiae at the basis. Propodus with two small teeth, dactylus with one small tooth. Other pereopods (Figure $1 \mathrm{c}-\mathrm{P}_{2}-\mathrm{P}_{5}$ ) morphologically very similar. The third is the largest, the fifth is the shortest. All pereopods have sparsely distributed simple and plumose setae. 


\section{General comments on different aspects observed in further stages}

From the first stage of the juvenile phase, in addition to the increase in size, important modifications occur on the carapace, abdomen, pleopods and chelipeds. There were no changes in shape of the cephalic and thoracic appendages, but an increase in the number of aesthetascs and setae occurred on each article. Branchial ontogeny was complete after the second juvenile stage: 1 pair of arthrobranchia and 1 pair of podobranchia in the second maxilliped; 2 pairs of arthrobranchiae and 1 pair of podobranchia in the third maxilliped; 2 pairs of arthrobranchiae and 1 pair of pleurobranchia in the first pereopod.

From the second stage of the juvenile phase, the carapace (Figure 4) has no lateral teeth and it becomes progressively wider than longer with stage changing (Table II). In the $9^{\text {th }}$ juvenile stage, carapace is very similar to the adult carapace.

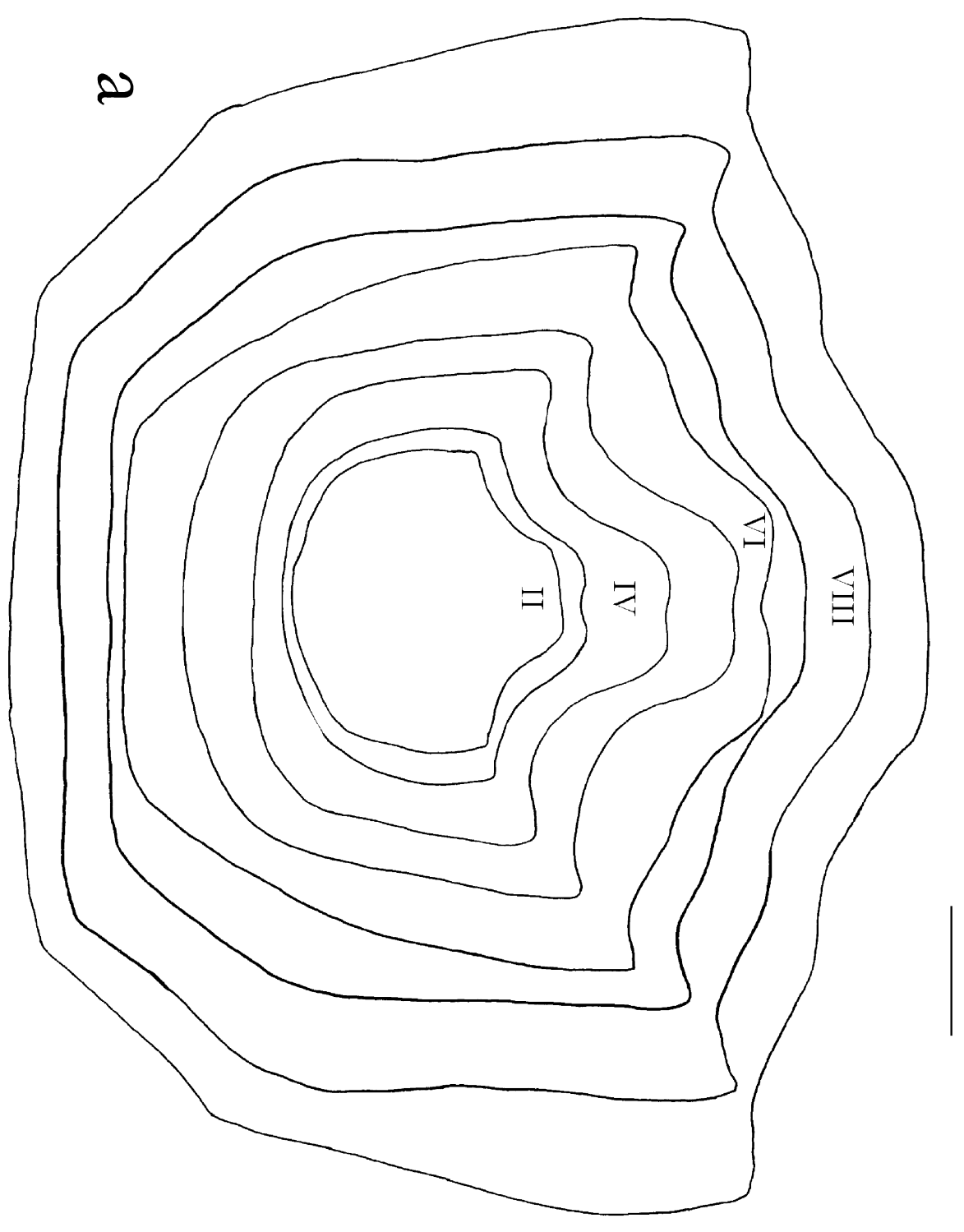

Figure 4 - Uca burgersi Holthuis, 1967. (a) carapace from second juvenile to ninth juvenile stage. Scale bar = $0.5 \mathrm{~mm}$. 
Table II - Uca burgersi Holthuis, 1967. Measurements in millimeters, of mean $(\bar{x})$ carapace length (CL) and carapace width $(\mathrm{CW})$. Variation expressed as standard deviation $(\mathrm{sd})$; number of observed crabs $(\mathrm{N})$ and carapace width/length ratio $(\mathrm{CW} / \mathrm{CL})$.

\begin{tabular}{|c|c|c|c|c|c|c|}
\hline Stages & \multicolumn{2}{|c|}{$\bar{x}$} & sd & Range & $\mathbf{N}$ & CW/CL \\
\hline J-I & $\begin{array}{l}\mathrm{CL} \\
\mathrm{CW}\end{array}$ & $\begin{array}{l}1.05 \\
1.01 \\
\end{array}$ & $\begin{array}{l}0.10 \\
0.03\end{array}$ & $\begin{array}{l}0.89-1.14 \\
0.97-1.05\end{array}$ & 10 & 0.96 \\
\hline $\mathrm{J}-\mathrm{II}$ & $\begin{array}{l}\mathrm{CL} \\
\mathrm{CW}\end{array}$ & $\begin{array}{l}1.30 \\
1.56 \\
\end{array}$ & $\begin{array}{l}0.02 \\
0.02 \\
\end{array}$ & $\begin{array}{l}1.54-1.58 \\
1.28-1.33 \\
\end{array}$ & 09 & 1.20 \\
\hline J-III & $\begin{array}{l}\mathrm{CL} \\
\mathrm{CW}\end{array}$ & $\begin{array}{l}1.65 \\
1.94 \\
\end{array}$ & $\begin{array}{l}0.08 \\
0.12\end{array}$ & $\begin{array}{l}1.54-1.75 \\
1.82-2.12 \\
\end{array}$ & 08 & 1.17 \\
\hline J-IV & $\begin{array}{l}\mathrm{CL} \\
\mathrm{CW}\end{array}$ & $\begin{array}{l}2.14 \\
2.31\end{array}$ & $\begin{array}{l}0.01 \\
0.03\end{array}$ & $\begin{array}{l}2.13-2.15 \\
2.28-2.35\end{array}$ & 08 & 1.08 \\
\hline $\mathrm{J}-\mathrm{V}$ & $\begin{array}{l}\mathrm{CL} \\
\mathrm{CW}\end{array}$ & $\begin{array}{l}2.23 \\
2.49 \\
\end{array}$ & $\begin{array}{l}0.01 \\
0.02\end{array}$ & $\begin{array}{l}2.22-2.24 \\
2.47-2.52\end{array}$ & 07 & 1.12 \\
\hline J-VI & $\begin{array}{l}\mathrm{CL} \\
\mathrm{CW}\end{array}$ & $\begin{array}{l}2.23 \\
2.70\end{array}$ & $\begin{array}{l}0.02 \\
0.02 \\
\end{array}$ & $\begin{array}{l}2.22-2.27 \\
2.68-2.73 \\
\end{array}$ & 07 & 1.21 \\
\hline J-VII & $\begin{array}{l}\mathrm{CL} \\
\mathrm{CW}\end{array}$ & $\begin{array}{l}2.49 \\
3.11 \\
\end{array}$ & $\begin{array}{l}0.02 \\
0.07 \\
\end{array}$ & $\begin{array}{l}2.47-2.51 \\
3.00-3.17 \\
\end{array}$ & 07 & 1.25 \\
\hline J-VIII & $\begin{array}{l}\mathrm{CL} \\
\mathrm{CW}\end{array}$ & $\begin{array}{l}3.06 \\
3.60\end{array}$ & $\begin{array}{l}0.02 \\
0.04\end{array}$ & $\begin{array}{l}3.03-3.09 \\
3.53-3.62\end{array}$ & 06 & 1.18 \\
\hline J-IX & $\begin{array}{l}\mathrm{CL} \\
\mathrm{CW}\end{array}$ & $\begin{array}{l}3.60 \\
4.53 \\
\end{array}$ & $\begin{array}{l}0.01 \\
0.04\end{array}$ & $\begin{array}{l}3.59-3.61 \\
4.50-4.56\end{array}$ & 02 & 1.26 \\
\hline$J-X$ & $\begin{array}{l}\mathrm{CL} \\
\mathrm{CW}\end{array}$ & $\begin{array}{l}4.50 \\
5.58 \\
\end{array}$ & & & 01 & 1.24 \\
\hline
\end{tabular}

Abdominal sexual dimorphism cannot be observed until the $5^{\text {th }}$ juvenile stage. From the $6^{\text {th }}$ stage, gender differences in abdominal morphology can be observed, as males have a smaller abdomen than the females (Figure $5 \mathrm{~J}-\mathrm{VI}$ ). Dimorphism of the abdomen is clear-cut from the $7^{\text {th }}$ juvenile stage (Figure $5 \mathrm{~J}$-VII - J-IX).
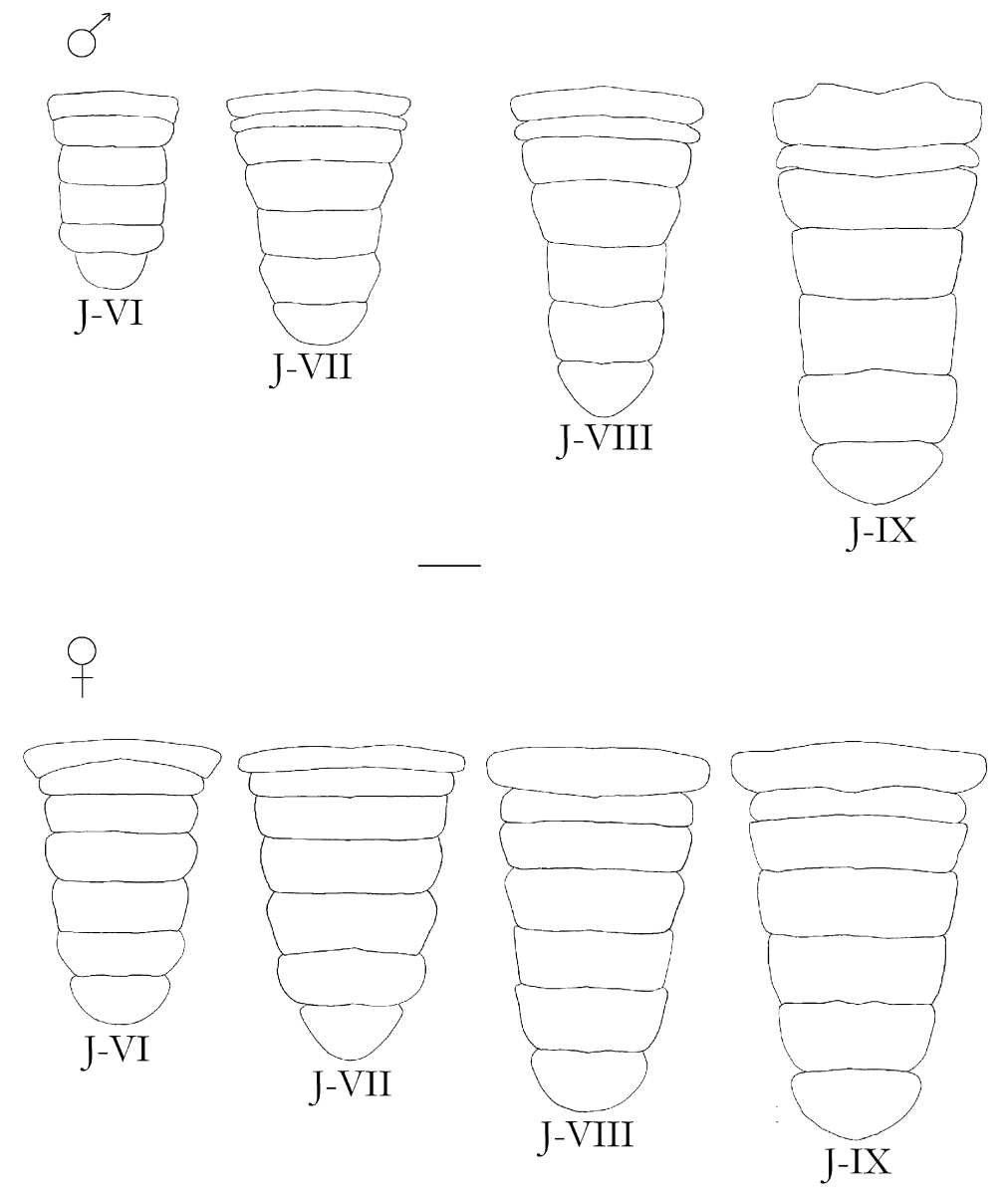

Figure 5 - Uca burgersi Holthuis, 1967. Abdomen from sixth juvenile stage to ninth juvenile stage (J-VI - J-IX). Scale bar $=0.5 \mathrm{~mm}$. 
After the first juvenile stage until the $3^{\text {rd }}$ juvenile stage all pleopods decrease in size (Figure $6 \mathrm{~J}-\mathrm{II}-\mathrm{J}$ III). In the $4^{\text {th }}$ stage (Figure $6 \mathrm{~J}-\mathrm{IV}$ ) males have two pairs of pleopods, one pair in the first and one pair in the second abdominal somite. Females have four pairs of pleopods (Figure $6 \mathrm{~J}$-IV), one pair in each abdominal somite (from the second to the fifth). From the $4^{\text {th }}$ juvenile stage, all pleopods increase in size (Figure $6 \mathrm{~J}-\mathrm{IV}-\mathrm{J}$-VII and Figure $7 \mathrm{~J}$-VIII - J-IX). In J$\mathrm{V}$, first and second pairs of pleopods (Figure $6 \mathrm{PL}_{2}$ and $\left.\mathrm{PL}_{3}\right)$ in females ( 3 in total) are birramous. All pleopods of females are birramous in sixth juvenile stage (Figure $6 \mathrm{~J}-\mathrm{VI}-\mathrm{J}-\mathrm{IX}$ ), with endopod longer than exopod. There are 3 males and 3 females in J-VIII and the first pleopods (Figure 7-PL $\mathrm{L}_{1}$ ) of males with 3(4-5) simple setae, second pleopod without setae (Figure 7- $\mathrm{PL}_{2}$ ); in females endopods are 2segmented, first pleopod without setae; second with 2(3-5) simple setae on proximal segment and 1(2) simple setae on distal segment of endopod; third and fourth pleopod without setae. In the J-IX (Figure 7 $\left.\mathrm{PL}_{1}-\mathrm{PL}_{2}\right)$, first pleopod $\left(\mathrm{PL}_{1}\right)$ of males has eight simple setae, second without setae $\left(\mathrm{PL}_{2}\right)$; females (Figure 7 $\left.\mathrm{PL}_{2}-\mathrm{PL}_{5}\right)$ have simple setae on all exopod and endopod of pleopod.
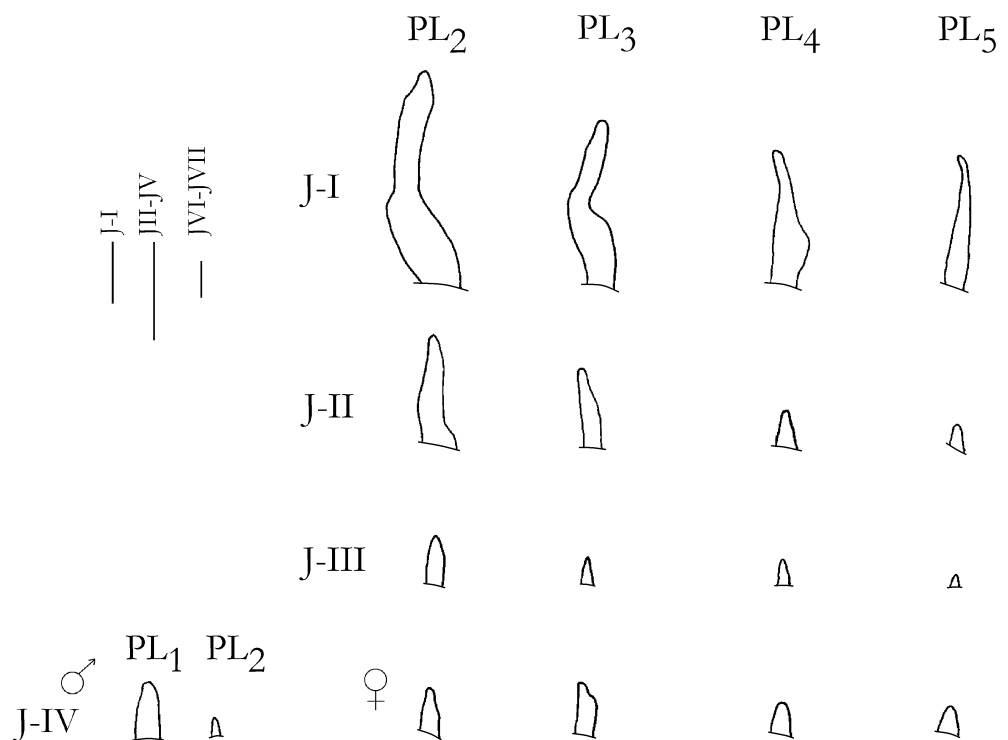

Q

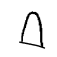

$\triangle$

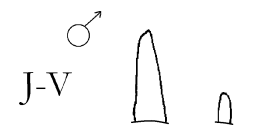

q

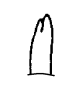

$\triangle$
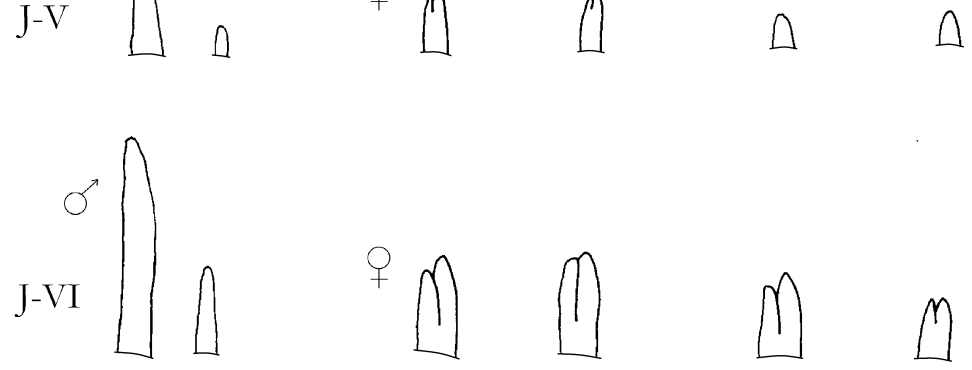

q
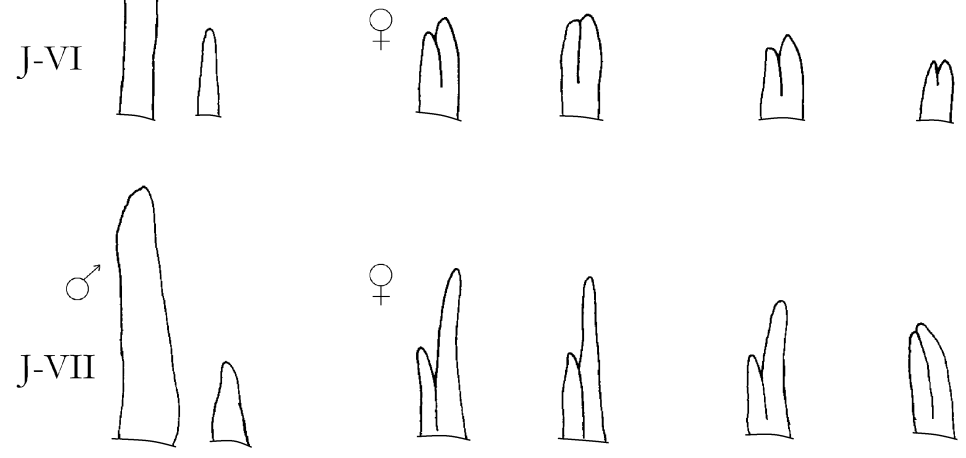
Figure 6 - Uca burgersi Holthuis, 1967. Pleopods from first juvenile to seventh juvenile stage (J-I - J-VII). Scale bars $=0.1 \mathrm{~mm}$.
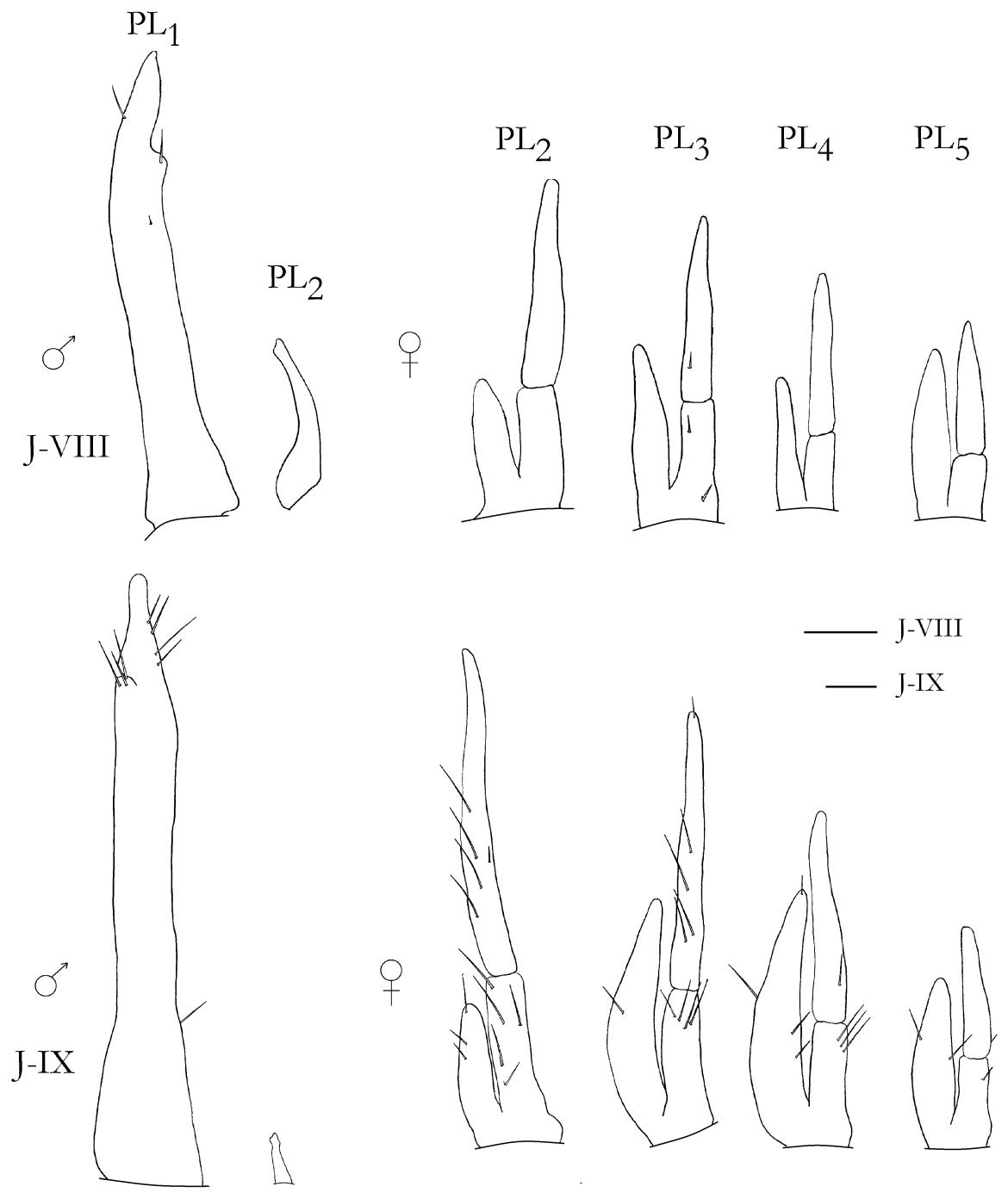

Figure 7 - Uca burgersi Holthuis, 1967. Pleopods from eight juvenile to ninth juvenile stage (J-VIII - J-IX). Scale bars $=0.1 \mathrm{~mm}$.

A significant characteristic of the genus Uca, which can even be seen in the juvenile stages, is the asymmetry of the chelipeds of males. Until the $6^{\text {th }}$ juvenile stage (Figure $8 \mathrm{~J}-\mathrm{VI}$ ) no dimorphism of chelipeds is found. In $7^{\text {th }}$ stage (Figure $8 \mathrm{~J}$-VII), chelipeds of males start to be slightly larger than chelipeds of females; however no asymmetry between male chelipeds is noticed. In $8^{\text {th }}$ stage (Figure $8 \mathrm{~J}$ VIII), a slight difference between right and left cheliped of males is noticed, as the right cheliped tends to have a slightly bulkier propod than the left cheliped. 


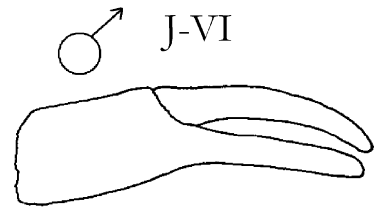

J-VII
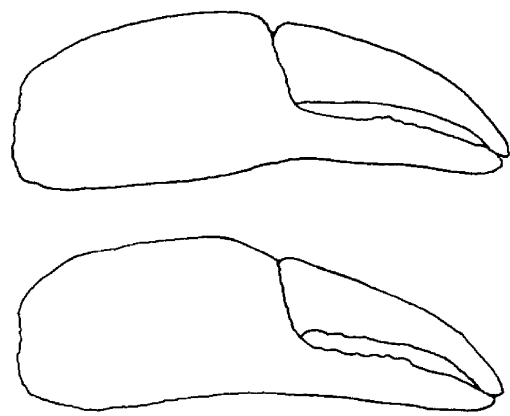

\section{J-VIII}
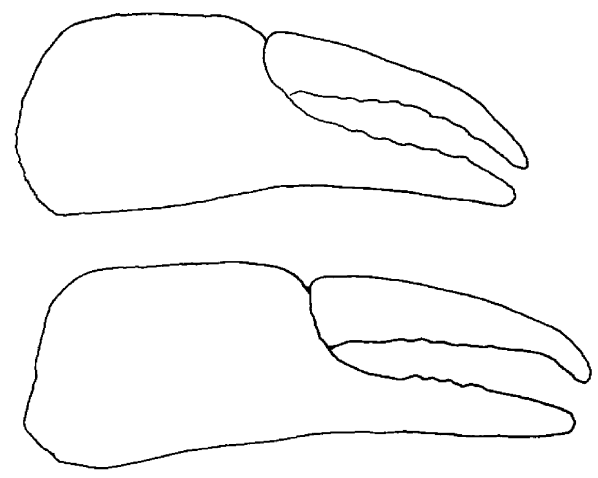

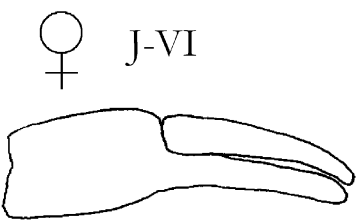

J-VII
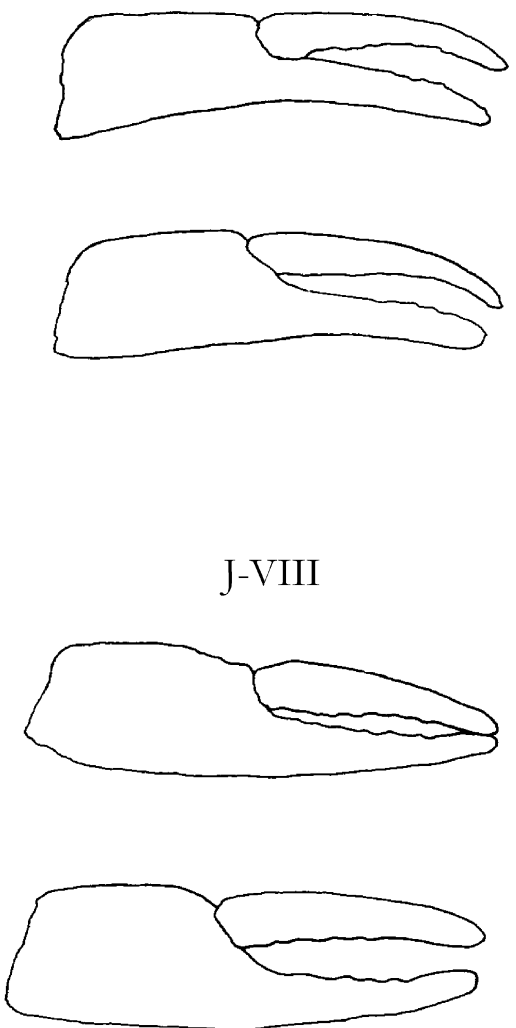

Figure 8. - Uca burgersi Holthuis, 1967. Chelipeds from sixth juvenile stage to eight juvenile stage (J-VI - J-VIII). Scale bars $=0.5 \mathrm{~mm}$.

\section{DISCUSSION}

One of the most striking morphological changes in juvenile stages of Brachyura is a marked change of the abdomen of females, which forms an incubating chamber in which the eggs will develop. Abdominal dimorphism of females, in Uca burgersi has been observed from the $6^{\text {th }}$ juvenile stage onwards, as in Pilumnus vestitus Haswell, 1882 (Pilumnidae) (Hale 1931). In Inachus dorsettensis (Pennant, 1777) (Inachidae) described by Ingle (1977) and Pyromaia tuberculata (Lockington, 1877) (Inachoididae) described by Flores et al. (2002) differentiation occurs in the $3^{\text {rd }}$ stage and in Pachygrapsus transversus (Gibbes, 1850) (Grapsidae) in the $7^{\text {th }}$ stage (Flores et al. 1998). In Panopeus austrobesus Williams, 1984 as Panopeus herbstii H. Milne-Edwards, 1834 (Panopeidae) (Hebling et al. 1982) and in Callinectes sapidus Rathbun, 1896 (Portunidae) (Barutot et al. 2001), no abdominal dimorphism occurs until the $8^{\text {th }}$ and $11^{\text {th }}$ juvenile stages.

Sexual differentiation is the main event in the juvenile phase of crabs and it can occur in many different stages, depending on the species. In Grapsoidea there is no pattern. For instance, in $P$. transversus, Neohelice granulata (Dana, 1851), Cyrtograpsus angulatus Dana, 1851 and Sesarma rectum Randall, 1840 differentiation occurs in the $2^{\text {nd }}$, $3^{\text {rd }}, 4^{\text {th }}$ and $12^{\text {th }}$ juvenile stage, respectively (Flores et al. 1998, Rieger \& Nakagawa 1995, Rieger \& Beltrão 
2000, Fransozo 1986/1987). In Xanthoidea such as Panopeus austrobesus, Eriphia gonagra (Fabricius, 1781), Eurypanopeus abbreviatus (Stimpson, 1860), Menippe nodifrons Stimpson, 1859 and Hexapanopeus caribbaeus, differentiation always occurs in the fourth stage (Hebling et al. 1982, Fransozo \& Negreiros-Fransozo 1987, Fransozo et al. 1988, Vieira 2000). Similar finding is reported for the Portunidae Callinectes sapidus studied by Barutot et al. (2001). In Uca pugilator the differentiation occurs when the carapace of juvenile reaches $3 \mathrm{~mm}$ of wider (Hyman 1920), while in U. burgersi, it occurs in the $4^{\text {th }}$ juvenile stage (2.31 $\mathrm{mm}$ of carapace width).

Sexual dimorphism in the size of the cheliped is reported to be the origin of the secondary sexual organ, which is important in the definition of territory as well as combat, display, courtship and mating

\section{ACKNOWLEDGEMENTS}

We are grateful to Dr. Gustavo Augusto S. Melo (Museu de Zoologia da Universidade de São Paulo) for confirmation of species identification. We thank to $\mathrm{Dr}^{\mathrm{a}}$. Maria Lucia Negreiros-Fransozo (Departamento de Zoologia, IBB - UNESP Campus de Botucatu, $\mathrm{SP}$ ) and Dr. Duane Barros Fonseca (Instituto de Oceanografia, FURG, RS) for valuable comments on the manuscript.

\section{REFERENCES}

AHMED, M. 1978. Development of asymmetry in the fiddlers crab Uca cumulanta Crane, 1943 (Decapoda, Brachyura). Crustaceana, 34(3): 294-300.

ANGER, K, M MONTÚ, C BAKKER \& LL FERNANDES. 1990. Larval development of Uca thayeri Rathbun, 1900 (Decapoda: Ocypodidae) reared in the laboratory. Meeresforschung, 32: 276-294.

BARNWELL, FH. 1982. The prevalence of male right-handedness in the indo-west pacific fiddler crabs Uca vocans (Linnaeus) and U. tetragonon (Herbst) (Decapoda: Ocypodidae). J. Crust. Biol., 2(1): 70-83.

BARUTOT, RA, RRR VIEIRA \& PJ RIEGER. 2001. Desenvolvimento juvenil de Callinectes sapidus Rathbun, 1896 (Crustacea: Decapoda: Portunidae), em laboratório, a partir de megalopas coletadas no plâncton. Comun. Mus. Ciênc. Tecnol. PUCRS Ser. Zool., 14(1): 23-42.

BENETTI, AS, \& ML NEGREIROS-FRANSOZO. 2004. Relative growth of Uca burgersi (Crustacea, Ocypodidae) from two mangroves in the southeastern Brazilian coast. Iheringia, Ser. Zool., 94(1): 67-72.

BOTTO, F, \& O IRIBARNE. 2000. Contrasting effects of two burrowing crabs (Chasmagnathus granulata and Uca uruguayensis) on sediment composition and transport in estuarine environments. Estuar. Coast. Shelf Sci., 51: 141-151.

CLARK, PF, DK CALAZANS \& GW POHLE. 1998. Accuracy and
(Hartnoll 1988). Until sexual differentiation in Uca, chelipeds are symmetrical in both sexes. When sexual differentiation takes place, at around $3 \mathrm{~mm}$ width of carapace in $U$. pugilator, at approximately $1.7 \mathrm{~mm}$ width of carapace in Uca cumulanta Crane 1943 (Hyman 1920, Ahmed 1978) and in the seventh juvenile stage (3.11 $\mathrm{mm}$ carapace width) in $U$. burgersi, either right or left cheliped of males becomes slightly larger than the counter side. Unfortunately, few individuals were obtained in order to establish in which side heterochely predominates during the development of $U$. burgersi. Nevertheless, while left heterochely was reported in adult populations of $U$. burgersi by Crane (1975), right heterochely in cogeneric species [U. vocans (Linnaeus 1758) and in $U$. tetragonon (Herbst 1790)] was reported by Barnwell (1982).

standardization of brachyuran larval descriptions. Invertebr. Reprod. Dev., 33(2-3): 127-144.

COELHO, PA. 1965/6. Os crustáceos decápodos de alguns manguezais Pernambucanos. Trab. Inst. Oceanogr. Univ. Fed. Pernambuco, 7/8: 71-90.

COELHO, PA \& M RAMOS-PORTO. 1980. Crustáceos Decápodos da Costa do Maranhão, Brasil. Bol. Inst. Oceanogr. São Paulo, 29(2): 135-138.

COLPO, KD \& ML NEGREIROS-FRANSOZO. 2003. Reproductive output of Uca vocator (Herbst, 1804) (Brachyura, Ocypodidae) from three subtropical mangrove in Brazil. Crustaceana, 76: 1-11.

CONDE, JE \& H Diaz. 1985. Diseño de muestro aleatorio estratificado aplicado al estudio de poblaciones del genero Uca (Brachyura, Ocypodidae). Invest. Pesq., 49(4): 567-579.

COSTA, TM \& ML NEGREIROS-FRANSOZO. 2002. Population biology of the fiddler crab Uca thayeri Rathbun, 1900 (Brachyura, Ocypodidae) in a subtropical South American mangrove area: Results from transect and catch-per-unit-effort techniques. Crustaceana, 75: 1201-1218.

CRANE, WF. 1975. Fiddlers crabs of the world. Ocypodidae: Genus Uca. New Jersey, Princenton University Press. xxiv+736p.

DINIZ-FILHO, JAF. 1990. Multivariate morphometrics and evolutionary patterns in some species of the genus Uca Leach 1814 (Crustacea: Brachyura: Ocypodidae). Rev. Bras. Gen., 13(4): 687-696.

FLORES, AAV, ML NEGREIROS-FRANSOZO \& A FRANSOZO. 1998. The megalopa and juvenile development of Pachygrapsus transversus (Gibbes, 1850) (Decapoda, Brachyura) compared with other grapsid crabs. Crustaceana, 71(2): 197-222.

FLORES, AAV, FPL MARQUES, \& ML NEGREIROS-FRANSOZO. 2002. Postlarval stages and growth patterns of the spider crab Pyromaia tuberculata (Brachyura, Majidae) from laboratoryreared material. J. Crust. Biol., 22(2): 314-327.

FRANSOZO, A. 1986/87. Desenvolvimento dos estágios juvenis de Sesarma (Holometopus) rectum Randall, 1840 (Decapoda, 
Grapsidae) obtidos em laboratório. Naturalia, 11/12: 77-87.

FRANSOZO, A. \& ML NEGREIROS-FRANSOZO. 1987. Morfologia dos primeiros estágios juvenis de Eriphia gonagra (Fabricius, 1781) e Eurypanopeus abbreviatus (Stimpson, 1860) (Crustacea, Decapoda, Xanthidae), obtidos em laboratório. Pap. Avuls. Zool., 36(22): 257-277.

FRANSOZO, A, ML NEGREIROS-FRANSOZO \& CM HIYODO. 1988. Developpement juvenile de Menippe nodifrons Stimpson, 1859 (Crustacea, Decapoda, Xanthidae) au laboratoire. Rev. Hydrobiol. Trop., 21(4): 297-308.

GENONI, GP. 1985. Food limitation in salt marsh fiddler crabs Uca rapax (Smith) (Decapoda: Ocypodidae). J. Exp. Mar. Biol. Ecol., 8: 97-110.

GENONI, GP. 1991. Increased burrowing by fiddler crabs Uca rapax (Smith) (Decapoda: Ocypodidae) in response to low food supply. J. Exp. Mar. Biol. Ecol., 147: 267-285.

HALE, HM. 1931. The post-embryonic development of an australian xanthid crab (Pilumnus vestitus Haswell). Rec. South Aust. Mus., 4: 321-331.

HARTNOLL, RG. 1988. Growth and molting. In: BURGGREN, WW \& BR McMAHON (eds). Biology of the land crabs. Cambridge University Press, 186-210.

HEBLING, NJ, A FRANSOZO \& ML NEGREIROS-FRANSOZO. 1982. Desenvolvimento dos primeiros estágios juvenis de Panopeus herbstii H. Milne-Edwards, 1834 (Crustacea, Decapoda, Xanthidae) criados em laboratório. Naturalia, 7: 177-188.

HYMAN, OW. 1920. The development of Gelasimus after hatching. J. Morphol., 33(2): 485-525.

INGLE, RW. 1977. The larval and post-larval development of the scorpion spider crab, Inachus dorsettensis (Pennant) (Family: Majidae), reared in the laboratory. Bull. Br. Mus. (Nat. Hist.) Zool., 30: 331-348.

KELLMEYER, K \& M SALMON. 2001. Hatching rhythms of Uca thayeri Rathbun: timing in semidiurnal and mixed tidal regimes. J. Exp. Mar. Biol. Ecol., 260: 169-183.

LOPEZ, LAG. 1980. Primera comunicacion a un estudio morfologico y bioecologico de Uca uruguayensis Nobili, 1901. Rev. Fac. Human. Cienc. Ser. Cienc. Biol., 1(11): 153-199.

MARTIN, JW, DL FELDER \& FM TRUESDALE. 1984. A comparative study of morphologie and ontogeny in juvenile stages of four western Atlantic xanthoid crabs (Crustacea: Decapoda: Brachyura). Philos. Trans. R. Soc. Lond. Series B., 303: 537-604.

MELO, GAS. 1996. Manual de Identificação dos Brachyura (Caranguejos e Siris) do litoral brasileiro. Plêiade/FAPESP, 604p.

MURAOKA, K. 1976. The post-larval development of the Uca lactea (de Haan) and Macrophthalmus (Mareotis) japonicus (de Haan) (Crustacea, Brachyura, Ocypodidae). Zool. Mag., 8: 40-51.

NEGREIROS-FRANSOZO, ML, KD COLPO \& TM COSTA. 2003. Allometric growth in the fiddler crab Uca thayeri (Brachyura, Ocypodidae) from a subtropical mangrove. J. Crust. Biol., 23(2): 273-279.
NOVAK, A \& M SALMON. 1974. Uca panacea, a new species of fiddler crab from the gulf coast of the United States. Proc. Biol. Soc. Wash., 87(28): 313-326.

O'CONNOR, NJ. 1990. Morphological differentiations and molting of juvenile fiddler crabs (Uca pugilator and U. pugnax). J. Crust. Biol, 10(4): 608-612.

OLIVEIRA, LPH. 1939. Contribuição ao conhecimento dos crustáceos do Rio de Janeiro. Gênero Uca (Decapoda, Ocypodidae). Mem. Inst. Oswaldo Cruz, 34(1): 115-148.

RIEGER, PJ. 1996. Desenvolvimento larval de Uca (Celuca) uruguayensis Nobili, 1901 (Crustacea, Decapoda, Ocypodidae), em laboratório. Nauplius, 4: 73-103.

RIEGER, PJ. 1997. Desenvolvimento larval de Uca (Minuca) mordax (Smith, 1870) (Crustacea, Decapoda, Ocypodidae), em laboratório. Trab. Inst. Oceanogr. Univ. Fed. Pernambuco, 25: 227-267.

RIEGER, P.J. 1998. Desenvolvimento larval de Uca (Minuca) burgersi Holthuis (Crustacea, Decapoda, Ocypodidae) em laboratório. Rev. Bras. Zool., 15(3): 727-756.

RIEGER, PJ. 1999. Desenvolvimento larval de Uca (Minuca) vocator (Herbst, 1804) (Crustacea, Decapoda, Ocypodidae), em laboratório. Nauplius, 7: 1-37.

RIEGER, P. J. \& NAKAGAWA, C. 1995. Desenvolvimento juvenil de Chasmagnathus granulata Dana, 1851 (Crustacea, Decapoda, Grapsidae), em laboratório. Nauplius, 3: 59-74.

RIEGER, PJ. \& R BELTRÃO. 2000. Desenvolvimento juvenil de Cyrtograpsus angulatus Dana (Crustacea, Decapoda, Grapsidae), em laboratório. Rev. Bras Zool., 17(2): 405-420.

ROSENBERG, MS. 2001. The systematics and taxonomy of fiddler crabs: a phylogeny of the genus Uca. J. Crust. Biol., 21(3): 839869.

SALMON, M. 1987. On the reproductive behavior of the fiddler crab Uca thayeri, with comparisons to $U$. pugilator and $U$. vocans: evidence for behavioral convergence. J. Crust. Biol., 7(1): 25-44.

SANTOS, S, PM SOUZA, P GOES, \& CM PEGORER. 1994. Os Brachyura semiterrestres (Crustacea, Decapoda) de llha Comprida, Brasil. Arq. Biol. Tecnol., 37: 417-427.

SPIVAK, ED, MA GAVIO \& E NAVARO. 1991. Life history and structure of the world's southernmost Uca population: Uca uruguayensis (Crustacea, Beachyura) in mar chiquita lagoon (Argentina). Bull. Mar. Sci., 48(3): 679-688.

VIEIRA, RRR. 2000. Desenvolvimento larval e juvenil de Hexapanopeus caribbaeus (Stimposn, 1871) (Crustacea, Decapoda, Xanthidae), em laboratório. 103p. Master Science Dissertation. Zoologia, Instituto de Biociências - UNESP, Botucatu, São Paulo, Brazil. 